\title{
David Clandfield, Bruce Curtis, Grace-Edward Galabuzi, Alison Gaymes San Vicente, David Livingstone and Harry Smaller Restacking the Deck: Streaming by Class, Race and Gender in Ontario Schools
}

Ottawa: OurSchools/OurSelves Special Issue 2014. 358 pp.

\author{
Jane Gaskell \\ Ontario Institute for Studies in Education, University of Toronto
}

Schools reproduce, and in many ways create inequality, rather than being the engines of equality that progressive educators hope for. This fact has been the subject of much academic work and the reason for a good deal of activism around schooling. The overall story, that elites manage to ensure their children maintain an advantage in the school system, remains the same over time and from place to place. But understanding the specific practices that advantage children from well off homes in any particular time and place helps policy makers and activists to be more effective.

There is never enough of this kind of work available in Canada, but there is some. Toronto has a particularly strong tradition of critical work on how schools disadvantage poor children, growing up around This Magazine is About Schools in the 1960s. In The Learning Machine (1974), journalist Loren Lind argued that schools were structured in a way that ensured the failure of students from working class backgrounds, and students who did not speak English. His critique reflected and motivated the work of a group of educational activists who managed to elect progressive trustees to the Toronto Board of Education. They tried to make the curriculum more responsive, to engage parents from less advantages homes, and eliminate streaming, using research and community organizing strategies. But this concerted effort over thirty years left streaming, and the relationship between social class and school success, firmly in place. ${ }^{1}$ 
In 1992, Bruce Curtis, David Livingstone and Harry Smaller published Stacking the Deck: The Streaming of Working Class Kids in Ontario Schools. It came on the heels of the Radwanski Commission Report (1987) which was critical of the amount of streaming students experienced in Ontario secondary schools. Stacking the Deck brought together statistical evidence with a critique of schooling - "biases against those from less affluent backgrounds are inherent in the form and content of the public school system" (1) - to demonstrate how schooling protected the advantages of middle-class students and systematically humiliated working-class students. ${ }^{2}$

And here we are in 2014, with a new book, called Restacking the Deck, expanding the argument from 150 pages to over 350, and from three authors to six, tackling a wider variety of equity issues explicitly, and coming to the same overall conclusions: "Streaming based on class, race, gender and imputed special needs still occurs extensively in our schools. What has changed is that the most evident consequences of streaming are being deferred" (1). More students are graduating from high school, but the outcomes are still unequal, and they are particularly unequal if we include postsecondary education and labour market outcomes in the analysis.

Restacking the Deck provides up-to-date evidence, from a wide variety of sources, that inequality is still systemic. There is a nice historical overview chapter by Bruce Curtis. The extended analysis of special education programs is particularly interesting. The Toronto District School Board (TDSB) has lots of data, and it is clear that "the poorer the children, the less likely they are to be considered gifted, the more likely they are to be considered as exceptional underperformers" (157). The push for inclusion has stalled and the outcomes from special education programs are not encouraging.

A chapter on race focuses on the overrepresentation of racialized youth in lower academic streams, special education classes, at risk discourses and "safe school" policies. A chapter on gender finds sexism alive and well and explores the intersectionality of gender with race, class, and ability. The book has much useful information.

It is a political book with a local audience in mind. It is designed for a general readership, although it sounds academic (many references and tables) and the prose can be turgid (structural dominance theories, material conditions, and racializing practices). It comes from the Centre for Policy Alternatives and includes ads from a variety of unions. It aims to mobilize groups for a political movement to change schooling, and confronts the problem that teachers themselves are some of the biggest supporters of continued streaming in the schools.

The book is a contrast and a companion to a report put out in 2014 by People for Education an Ontario community group focusing on public education issues. Their report (Choosing Courses for High School) provides a short, narrowly focused, widely distributed argument that Applied stream courses are not serving students well. Restacking the Deck provides a full-blown theoretical and political analysis for the serious reader, and it deserves a wide audience.

While it is very useful to have a local Ontario focus, a little more international context would be helpful. There is little reference to international work that provides a very strong, research-based case against streaming, along with policy prescriptions 
for changing it, and experience of struggles in other school districts. (For example, see the work of Jeannie Oakes. ${ }^{3}$ ) And there is no discussion of whether the content and structure of Ontario education are any better or worse than other jurisdictions, although this has been the focus of quite a lot of debate recently. Canada shows up relatively well compared to other jurisdictions, on the Organisation for Economic Co-operation and Development (OECD)'s Programme for International Student Assessment (PISA) measures of inequality, despite the continuing inequality that is clearly present here.

\section{Notes}

1 Jane Gaskell and Benjamin Levin, Making a Difference in Urban Schools: Ideas, Politics, and Pedagogy (Toronto: University of Toronto Press, 2012).

2 Bruce Curtis, D. W. Livingstone, and Harry Smaller, Stacking the Deck: The Streaming of Working-Class Kids in Ontario Schools (Toronto: Our Schools/Our Selves, 1992).

3 Jeannie Oakes, Keeping Track: How Schools Structure Inequality, $2^{\text {nd }}$ ed. (New Haven: Yale University Press, 2005). 